\title{
Synthesis, Characterization and Biological Activity of Some Heterocyclic Compounds Containing Quinoline Molecule
}

\author{
Sarah Abdulhamza Hameed ${ }^{1}$, Hiba H. Ibraheem ${ }^{1}$ \\ ${ }^{1}$ Chemistry Division, Department of Applied Science, University of Technology, Baghdad-Iraq.
}

\begin{tabular}{ll}
\hline Articles Information & Abstract \\
\hline Received: & This work includes "organic" composition while biologically probe for \\
$29,09,2019$ & several modern heterocyclic derivatives via 3 steps: Firstly synthesis \\
Accepted: & from some 5-membered. heterocyclic derivatives (Pyrazole while \\
$29,01,2020$ & isoindoline-1,3-dione) from quinoline. Secondly included characterized \\
Published: & and confirmed by using melting point, TLC, infrared spectrum analysis \\
01, March, 2020 & while'H-NMR. Thirdly ncluded the examination of biological activity of \\
& some components against (4) varieties of pathogen bacteria \\
Keywords: & (Staphylococcus aureus, Staphylococcus epidermidis) gram-positive and \\
Quinoline & (Escherichia coli, Klebsiella sp.) gram-negative and fungal infections \\
Pyrazole & (Candida albicans). The results of whole derivatives show stellar \\
Heterocyclic derivatives & biological activity compared to antibiotics (gentamycin). \\
Antibacterial. &
\end{tabular}

DOI: 10.22401/ANJS.23.1.01

* Corresponding author: dr.hiba1982@gmail.com

\section{Introduction}

Heterocyclic organic compounds are the cyclic components that have atoms from onto the minimum two dissimilar items acting as members from its ring [1]. The heterocyclic component has been helpfully categorized based according to its electronic structure. The saturated heterocycles organic compounds conduct such as the acyclic derivatives. Consequently, piperidine, tetrahydrofuran have been traditional amines while ethers, for reasonable stars profiles, thus, focuses particularly study heterocyclic chemistry during unsaturated derivatives. While the preponderance from work implementations include unstrained 5, 6-membered rings such as pyridine, thiophene, pyrrole, and furan. Else great group from heterocycles were joined upon benzene loops, which to pyrrole, furan, pyridine, benzothiophene, quinoline, indole, thiophene, and benzofuran. Blend from two benzene rings accord rise upon a third big family from compounds, the acridine, dibenzothiophene, carbazole, and dibenzofuran. The unsaturated heterocyclic organic compounds rings have been categorized agreeing upon the involvement from the heteroatom onto the combined system, pi system [2] several from the widespread heterocyclic compounds utilized by the medicines were being amino acids, for instance, histidine, proline while a vitamins, tryptophan, co- $^{-}$ enzymes precursors like pyridoxine, B12, riboflavin, thiamine, folic acid, E families from the vitamins, and biotin. There was being a large number from pharmacologically effective heterocyclic "organic" component, a lot from who has to be within orderly clinical utilize. The pyrimidines while its derivatives were a pivotal part within biological qualities. 2-Sulphanilamidopyrimidines viz. sulphadiazine, sulphamethoxydiazine and sulphadiazine have fully -celebrated antibacterial agents [3]. In abundant natural products have been lead Quinoline scaffolding while they exhibit remarkable biological activities such as antimalarial, antibacterial, antiasthmatic, antihypertensive, anti-inflammatory agents and antiobesity [4-6]. The derivative of pyrazole compounds have been utilized variouslu as a molecule within the pharmaceutical evolution while have a vast range from biological action, antibacterial, antifungal and pharmacological efficiencies like anti-inflammatory, antitubercular, anticancer, analgesic, antipyretic, and anticonvulsant efficiencies [7-9]. In this work, we investigated a simple synthesis the chain form fivemembered heterocyclic derivatives (Pyrazole \& isoindoline-1,3-dione) derived from quinolone. The 


\section{Al-Nahrain Journal of Science}

ANJS, Vol.23 (1), March, 2020, pp. 1 - 6

components were synthesized and evaluated for their antibacterial and antifungal activities as comparison with standard drugs. Reaction sequences of the synthesized compounds have appeared in Scheme (1,2 \& 3).<smiles>O=Cc1ccccc1O</smiles>

2-hydroxybenzaldehyde<smiles>CCOC(=O)c1ccc(/N=N/c2ccc(O)c(C=O)c2)cc1</smiles>

Scheme 1. Synthesis of Azo Derivative.<smiles>O=c1ccc2ccccc2o1</smiles><smiles>Cn1c(=O)cc(N)c2ccccc21</smiles>

(1) $\mathrm{NH}_{2}$

EtOH<smiles>COC(=O)c1ccc(/N=N/c2ccc(O)c(/C=N/n3c(=O)ccc4ccccc43)c2)cc1</smiles><smiles>NC(=O)c1ccc(/N=N/c2ccc(O)c(/C=N/n3c(=O)ccc4ccccc43)c2)cc1</smiles>

Scheme 2. Synthesis of acid hydrazide derivative from Quinoline.

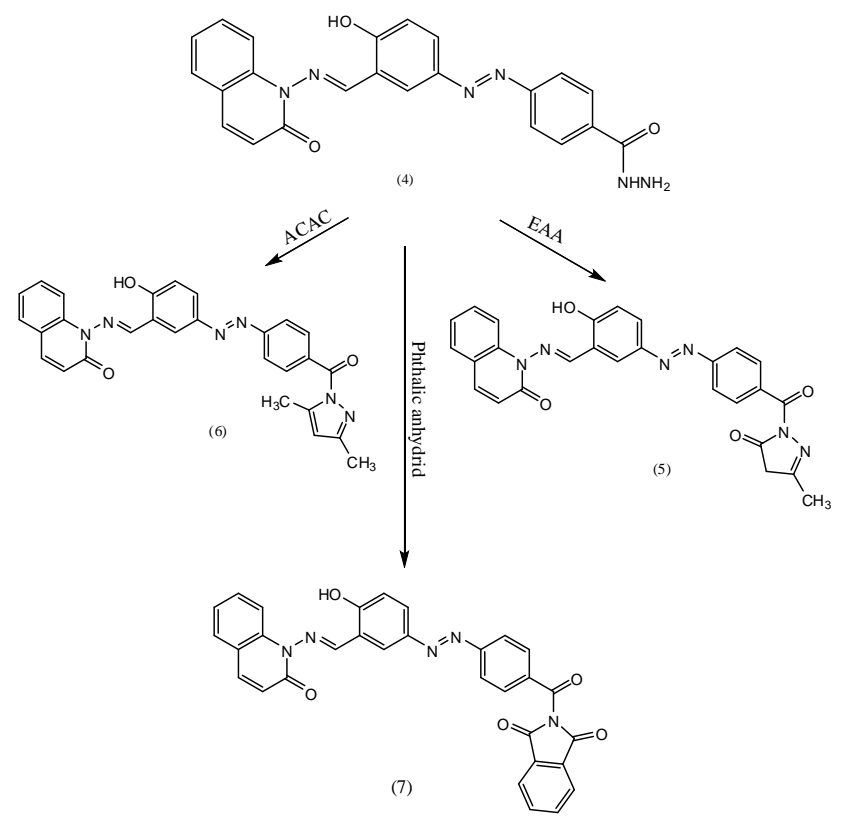

Scheme 3. Synthesis some heterocyclic compounds from acid hydrazide derivative.

\section{Experimental}

2.1 Synthesis of 1-aminoquinolin-2 (1H) -one (1)

A mixture of $2 \mathrm{H}$-chrome-2-one (0.02 mole) in ethanol $(25 \mathrm{ml})$, is added dropwise hydrazine hydrate (80\%) (1g, 0.02 moles) with string [10]. The mixture was refluxed for $24 \mathrm{hrs}$. After cooling mixture the solid formed was filtrated off and recrystallized from ethanol: water $(1: 1)$ to give compound (1), white precipitate, yield 88\%, M.P $\left(136-138^{\circ} \mathrm{C}\right)$. The FTIR spectral data showed absorption at $\left(1639 \mathrm{~cm}^{-1}\right.$, for $v \mathrm{C}=\mathrm{O}$, quinoline), $\left(1597,1452 \mathrm{~cm}^{-1}\right.$, for $\left.\mathrm{vC}=\mathrm{C}, \mathrm{Ar}.\right),\left(3045 \mathrm{~cm}^{-1}\right.$, for $\mathrm{vC}^{-}$ $\mathrm{H}, \mathrm{Ar}.),\left(1242 \mathrm{~cm}^{-1}\right.$, for $\left.\mathrm{vC}-\mathrm{N}\right)$ and $\left(3292,3199 \mathrm{~cm}^{-1}\right.$, for $\left.\mathrm{vNH}_{2}\right)$. ${ }^{1} \mathrm{H}-\mathrm{NMR}$ spectra data showed signal at $4.2\left(\mathrm{~s}, 2 \mathrm{H}, \mathrm{NH}_{2}^{-}\right), 6.8-7.5\left(\mathrm{~m}, 6 \mathrm{H}, \mathrm{Ar}^{-} \mathrm{H}\right)$.

\subsection{Synthesis of Azo Derivative (2)}

Ethyl 4-aminobenzoate (0.01 mole) was added to the concentrated hydrochloric acid $(4.5 \mathrm{ml})$ and a mixture of water $(4 \mathrm{ml})$. The product mixture was stirred for $10 \mathrm{~min}$. Cooling the solution to (0-5) 0 ${ }^{\circ} \mathrm{C}$. Adding water drop wise $(2.5 \mathrm{ml})$ to a solution of sodium nitrite $(0.69 \mathrm{~g}, 0.01$ mole $)$ with stirring for 10 min. After that adding drop wise the product solution of diazonium salt to a mixture of salicylaldehyde $(1.22 \mathrm{~g}, 0.01$ moles $)$ in ethanol and $10 \% \mathrm{NaOH}(10 \mathrm{~mL}$.$) in (0-5) 0{ }^{\circ} \mathrm{C}$ in $\mathrm{pH}=5.5$ while the disappearing from reactants was figured as stated by TLC technique. Later after finishing all additives the mixture was stirred for further 20 min. After that left for (one hour). The product solid was filtered off and dry while recrystallized from ethanol to give compound (2), Yellow precipitate, 


\title{
Al-Nahrain Journal of Science
}

\author{
ANJS, Vol.23 (1), March, 2020, pp. 1 - 6
}

yield $81 \%$, Melting point $\left(160-162 \mathrm{C}^{\circ}\right)$. The FTIR spectral data showed absorption at $(1660 \mathrm{~cm}-1$, for $\mathrm{uC}=\mathrm{O}), \quad\left(1580,1475 \mathrm{~cm}^{-1}, \quad\right.$ for $\left.\mathrm{uC}=\mathrm{C}, \quad \mathrm{Ar}.\right)$, (2930,2855cm-1, for $\mathrm{uCH}$, aliphatic), $\left(1710 \mathrm{~cm}^{-1}\right.$, for $\mathrm{uC}=\mathrm{O}$, ester), (3010 cm-1, for $\left.\mathrm{uC}^{-\mathrm{H}}, \mathrm{Ar}.\right),\left(1275 \mathrm{~cm}^{-1}\right.$, for $\left.\mathrm{uC}^{-} \mathrm{O}\right),\left(3200 \mathrm{~cm}^{-1}\right.$, for $\left.\mathrm{uOH}\right)$ and $\left(1570 \mathrm{~cm}^{-1}\right.$, for $\mathrm{uN}=\mathrm{N})$.

\subsection{Synthesis of Schiff base compound (3)}

Compound (1) (0.01mole) mix with (10 mL.) of absolute ethanol, and compound (2) (0.01mole) was refluxed for 10 hours in the presence of (3-4) drops of glacial acetic acid. The progress of the reaction was monitored by TLC (hexane: ethyl acetate, 7:3, $\mathrm{Rf}=0.81$ ). After cooling the formed solid product is filtered, dried and purified by recrystallized from ethanol [12], dark yellow product, yield 52\%, M.P $\left(328-330{ }^{\circ} \mathrm{C}\right)$. The FTIR spectral data showed absorption at $\left(1675 \mathrm{~cm}^{-1}\right.$, for $\mathrm{v} \mathrm{C}=\mathrm{O}$, quinoline), $\left(1626 \mathrm{~cm}^{-1}\right.$, for $\left.v \mathrm{C}=\mathrm{N}\right),\left(1427,1489 \mathrm{~cm}^{-1}\right.$, for $v \mathrm{C}=\mathrm{C}$, Ar.), (2993,2908 $\mathrm{cm}^{-1}$, for $\mathrm{vCH}$, aliphatic), (1711 $\mathrm{cm}^{-1}$, for $v \mathrm{C}=\mathrm{O}$, ester $)$, $\left(3055 \mathrm{~cm}^{-1}\right.$, for $v \mathrm{C}-\mathrm{H}$, Ar. $)$ and $\left(1577 \mathrm{~cm}^{-1}\right.$, for $\left.v \mathrm{~N}=\mathrm{N}\right)$.

\subsection{Synthesis of acid hydrazide derivative (4)}

Compound (3) (0.02 mole) mix with ethanol (25ml), hydrazine hydrate $(80 \%)(1 \mathrm{~g}, 0.02$ mole $)$ is added dropwise with mixing. The mixture was refluxed at $12 \mathrm{hrs}$. Later cooling the solid product, is filtered off, while recrystallized of ethanol: water (1:1) to get compound (4). Melting point: $118-120{ }^{\circ} \mathrm{C}$, white precipitate, Yields: 50\%. TLC (hexane: ethyl acetate, 7:3, $\mathrm{Rf}=0.78)$. The FTIR spectral data showed absorption at $\left(1680 \mathrm{~cm}^{-1}\right.$, for $\mathrm{C}=\mathrm{O}$, quinoline), $\left(1633 \mathrm{~cm}^{-1}\right.$, for $\mathrm{C}=\mathrm{O}$, amide $),(1533,1464$ $\mathrm{cm}^{-1}$, for $\left.\mathrm{C}=\mathrm{C}, \mathrm{Ar}.\right),\left(3182 \mathrm{~cm}^{-1}\right.$, for $\left.\mathrm{C}-\mathrm{H}, \mathrm{Ar}.\right),(1620$ $\mathrm{cm}^{-1}$, for $\left.\mathrm{C}=\mathrm{N}\right),\left(1570 \mathrm{~cm}^{-1}\right.$, for $\left.\mathrm{N}=\mathrm{N}\right)$ and $\left(3200^{-}\right.$ $3313 \mathrm{~cm}^{-1}$, for $-\mathrm{NHNH}_{2}$ ).

2.5 General procedure for synthesis of Pyrazoles.

A mixture of compound (4) (0.015mole) and ethyl acetoacetate (1.95g.,0.015mole) or acetylacetone (1.5gm.,0.015mole) in absolute ethanol $(25 \mathrm{ml}$.$) are$ refluxed for $24 \mathrm{hrs}$. as stated by the TLC technique was calculate disappearing from reactants. The reaction mixture cools to room temperature. The separated solid product is recrystallized from ethanol.

2.5.1 Synthesis of 1,2-hydroxy-5(4-(3-methyl-5-oxo4,5-dihydro-1H-pyrazole-1-

carbonyl)phenyl)diazenyl)benzylideneamino)quinoli $\mathrm{n}$-2(1H)-one (5)

Melting point: $210-212{ }^{\circ} \mathrm{C}$, brown precipitate, yields: 55\%. TLC (hexane: ethyl acetate, 7:3, $\mathrm{Rf}=0.61$ ). The FTIR spectral data showed absorption at $\left(1685 \mathrm{~cm}^{-1}\right.$, for $v \mathrm{C}=\mathrm{O}$, quinoline $), \quad\left(1741 \mathrm{~cm}^{-1}\right.$, for ${ }_{\mathrm{vC}}=\mathrm{O}$, for pyrazole ring), $\left(1716 \mathrm{~cm}^{-1}\right.$, for $\left.v \mathrm{C}=\mathrm{O}\right)$, $\left(1558,1521 \mathrm{~cm}^{-1}\right.$, for $\left.\mathrm{vC}^{-\mathrm{C}}, \mathrm{Ar}.\right),\left(3009 \mathrm{~cm}^{-1}\right.$, for $\mathrm{vC}-$ $\mathrm{H}, \mathrm{Ar}.),\left(1618 \mathrm{~cm}^{-1}\right.$, for $\left.\mathrm{vC}=\mathrm{N}\right),\left(1654 \mathrm{~cm}^{-1}\right.$, for $v \mathrm{C}=\mathrm{N}$, for pyrazole ring), (1572 $\mathrm{cm}^{-1}$, for $\left.\mathrm{vN}=\mathrm{N}\right)$ and (2852, $2924 \mathrm{~cm}^{-1}$, for $\mathrm{vCH}$, alphatic). ${ }^{1} \mathrm{H}-\mathrm{NMR}$ spectra data showed signal at $2.0\left(\mathrm{~s}, 3 \mathrm{H},-\mathrm{CH}_{3}\right), 2.3\left(\mathrm{~s}, 2 \mathrm{H},-\mathrm{CH}_{2}-\right)$, 6.6-9.0 $\left(\mathrm{m}, 14 \mathrm{H}, \mathrm{Ar}-\mathrm{H},-\mathrm{CH}^{-} \mathrm{CH}^{-}, \mathrm{N}=\mathrm{CH}^{-}\right)$and 11.3 (s, $1 \mathrm{H},-\mathrm{OH})$.

2.5.2 Synthesis of 1,5(4-(3,5-dimethyl-1H-pyrazole1-carbonyl)phenyl)diazenyl)-2-

hydroxybenzylideneamino)quinolin-2(1H)-one (6)

Melting point: 290-292 ${ }^{0} \mathrm{C}$, brown precipitate, yields: $52 \%$. TLC (hexane: ethyl acetate, 7:3, Rf = 0.63). The FTIR spectral data showed absorption at $\left(1680 \mathrm{~cm}^{-1}\right.$, for $v \mathrm{C}=\mathrm{O}$, quinoline $), \quad\left(1695 \mathrm{~cm}^{-1}\right.$, for $\mathrm{vC}=\mathrm{O}),\left(1518,1487 \mathrm{~cm}^{-1}\right.$, for $\left.\mathrm{vC}=\mathrm{C}, \mathrm{Ar}.\right),\left(3005 \mathrm{~cm}^{-1}\right.$, for $v \mathrm{C}-\mathrm{H}, \mathrm{Ar}.),\left(1618 \mathrm{~cm}^{-1}\right.$, for $\left.v \mathrm{C}=\mathrm{N}\right),\left(1654 \mathrm{~cm}^{-1}\right.$, for $\mathrm{v} \mathrm{C}=\mathrm{N}$, for pyrazole ring $), \quad\left(1572 \mathrm{~cm}^{-1}\right.$, for $\left.\mathrm{vN}=\mathrm{N}\right)$ and $\left(2852,2931 \mathrm{~cm}^{-1}\right.$, for $\mathrm{vCH}$, alphatic).

2.6 Synthesis of 2-(4(4-hydroxy-3(2-oxoquinolin1(2H)-ylimino)methyl)phenyl) diazenyl)benzoyl)isoindoline-1,3-dione (7)

Compound (4) (0.01 mole) mixed with (0.01 mole) phthalic anhydride (1.48gm., 0.01 mole) then heated within an oil bath for $10 \mathrm{~min}$. The reaction mixture cooled to room temperature. The separated solid product is recrystalized from ethanol. Melting point: oily, brown precipitate, yields: 67\%. TLC (hexane: ethyl acetate, 7:3, $\mathrm{Rf}=0.65$ ). The FTIR spectral data showed absorption at $\left(1685 \mathrm{~cm}^{-1}\right.$, for vC $=\mathrm{O}$, quinoline $),\left(1664 \mathrm{~cm}^{-1}\right.$, for $v \mathrm{C}=\mathrm{O}$, amide $)$, (1797, $1735 \mathrm{~cm}^{-1}$, for $\left.\mathrm{vC}=\mathrm{O}\right),\left(1523,1489 \mathrm{~cm}^{-1}\right.$, for vC $=\mathrm{C}$, Ar.), (3009 $\mathrm{cm}^{-1}$, for vC-H, Ar.), (1597 $\mathrm{cm}^{-1}$, for $v \mathrm{C}=\mathrm{N}),\left(1570 \mathrm{~cm}^{-1}\right.$, for $\left.\cup \mathrm{N}=\mathrm{N}\right)$ and $\left(3271 \mathrm{~cm}^{-1}\right.$, for $v-\mathrm{NH})$.

\subsection{Biological activity assay}

Pyrazole derivatives $(5,6)$ and isoindoline-1,3-dione (7) were screened for Antibacterial activity against for several types from bacteria such as, (Staphylococcus aureus, Staphylococcus epidermidis ) gram positive and ( Escherichia coli, Klebsiella sp.) gram negative and fungal infections (Candida albicans). Employ nutrient agar medium by way of very well diffusion method [13,14]. All derivatives compound were pendent within water solutions at various concentrations spread from one $\mathrm{mg}$ and $0.01 \mathrm{mg}$ within one hundred $\mathrm{mL}$. of DMSO, outcome are make known on MIC [minimal inhibitory concentration] while exhibiting high biological effectiveness from whole those synthesized compounds from those microorganisms more than the activity of antibiotics (gentamycin medication). Offer the biological realization within Table (1). 


\title{
Al-Nahrain Journal of Science
}

\author{
ANJS, Vol.23 (1), March, 2020, pp. 1 - 6
}

Table 1. Antimicrobial activities of some of the synthesized of these compounds with biological activity of gentamycin.

\begin{tabular}{|c|c|c|c|c|c|c|c|c|c|c|}
\hline \multirow{3}{*}{$\begin{array}{l}\text { Compound } \\
\text { Number }\end{array}$} & \multicolumn{4}{|c|}{ Gram positive } & \multicolumn{4}{|c|}{ Gram negative } & \multirow{2}{*}{\multicolumn{2}{|c|}{$\begin{array}{l}\text { Candida } \\
\text { albicans }\end{array}$}} \\
\hline & \multicolumn{2}{|c|}{ S. Aureus } & \multicolumn{2}{|c|}{$\begin{array}{l}\text { Streptococcus } \\
\text { epidermidis }\end{array}$} & \multicolumn{2}{|c|}{ E.Coli } & \multicolumn{2}{|c|}{ Klebsiella Sp. } & & \\
\hline & $1 \times 10^{-2}$ & $1 \times 10^{-3}$ & $1 \times 10^{-2}$ & $1 \times 10^{-3}$ & $1 \times 10^{-2}$ & $1 \times 10^{-3}$ & $1 \times 10^{-2}$ & $1 \times 10^{-3}$ & $1 \times 10^{-2}$ & $1 \times 10^{-3}$ \\
\hline (5) & - & - & 10 & 12 & 10 & 12 & - & 10 & - & 12 \\
\hline (6) & - & - & 12 & 10 & - & - & - & - & - & - \\
\hline (7) & - & - & 12 & 12 & & 10 & 12 & - & 11 & 12 \\
\hline Gentamycin & 10 & 8 & 10 & 8 & 10 & 8 & 10 & 8 & & \\
\hline
\end{tabular}

* Zone diameter of growth inhibition (mm) after 24 hours, at the different concentrations in DMSO.

\section{Results and Discussion}

\subsection{Chemistry}

A number of amine derivative have fully-celebrated with their useful as onset substance for synthesizing of another compounds, so for this purpose some aldehyde derivative (3) which was prepared by condensation_reaction between 1aminoquinolin-2(1H)-one (1) with (E)-ethyl-4-((3formyl-4-hydroxyphenyl) diazenyl) benzoate (2) within the being from ethanol as a solvent substance toethyl 4(4-hydroxy-3(2-oxoquinolin1(2H)-ylimino)methyl)phenyl)diazenyl)benzoate (3).

The electrophilic carbon atoms of aldehyde are often target of nucleophilic attack via amines. The ultimate outcome of that reaction is a compound within whose the $\mathrm{C}=\mathrm{O}$ double bond is change via a $\mathrm{C}=\mathrm{N}$ double bond. This kind from compound is understood as an imine, or Schiff base. The structure from the willing Schiff's bases was assured via infrared spectrum analysis. The FTIR spectra of compound (3) showed that the band of $\mathrm{NH}_{2}$ was indicated the disappeared $\mathrm{NH}_{2}$ within the region $(3292,3199) \mathrm{cm}^{-1}$ and the band at $(1626) \mathrm{cm}^{-1}$ due to $(\mathrm{C}=\mathrm{N})$ group.The pyrazole derivatives $(5,6)$ result via the reaction ethyl acetoacetate or acetyl acetone with hydrazide derivative (4).

The mechanism proceed ,frist by nucleophilic attack of $\left(\mathrm{NH}_{2}\right)$ group on ketonic carbonyl to form isomethene group and second nucleophilic attack of $(\mathrm{NH})$ group of hydrazide on esteric carbonyl to form pyrazole ring in the following steps $[15,16]$ :

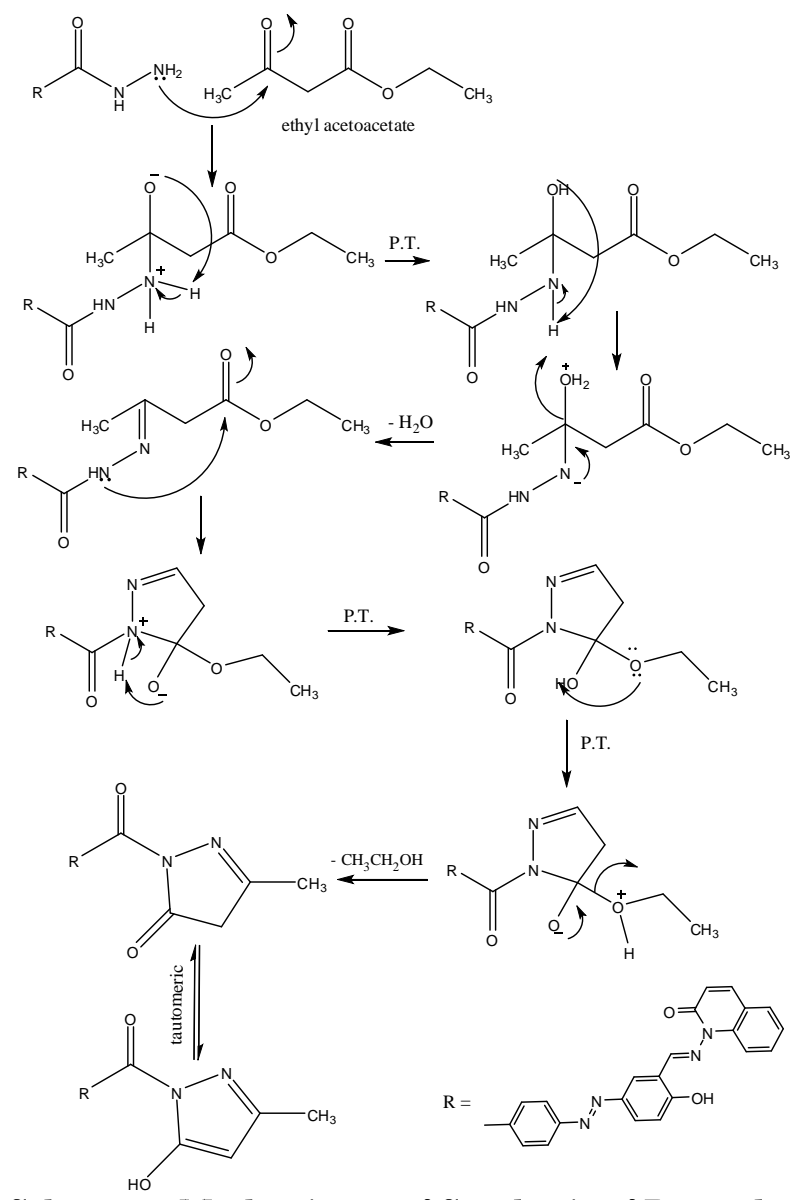

Scheme 4. Mechanisms of Synthesis of Pyrazoles derivative.

Hydrazine derivative (4) is the most common reagent used for the synthesis of phthalazinone derivative (7) via their reaction with phthalic anhydride. Fourier-transform infrared spectroscopy of compound (7) shows carbonyl group bands during $(1797,1735) \mathrm{cm}^{-1}$ of respectively and the disappearance $\left(-\mathrm{NHNH}_{2}\right)$ in $(3313-3200) \mathrm{cm}^{-1}$. 


\section{Al-Nahrain Journal of Science}

ANJS, Vol.23 (1), March, 2020, pp. 1 - 6

\subsection{Biological activity assay}

The development from antibiotics for bacterial pathogenesis includes special prominence within the curing of infection ailment .The antibacterial activity of the synthesized compounds (5-7) was evaluated against the bacterial strains Staphylococcus aureus and Streptococcus pyogenus (Gram +ve bacteria) and Escherichia coli and Klebsiella pneumniae (Gram -ve bacteria) by the disk diffusion method. Standard drug (Gentamycin) was used at a concentration of $10 \mathrm{mg} \mathrm{mL}^{-1}$ and 1 $\mathrm{mg} \mathrm{mL}-1$ for comparisons. Some of synthesized compounds showed highly effective even at low concentrations. The results also showed that some of synthesized compounds are effectively higher than the effectiveness of Gentamycin. The data obtained in Table (1) indicate that the All of these compounds (5-7) are higher than the activity from the residue from the Gentamycin. From the data obtaind in Table (1), it is found that compound (5) has highest activity against Escherichia coli (gramve bacteria) at solution $1 \mathrm{mg} \mathrm{m} L^{-1}$, compound (7) is found to have the highest activity against Streptococcus aureus and Staphylococcus epidermidis (Gram +ve bacteria) at solution $10 \mathrm{mg}$ $\mathrm{mL}^{-1}$ and $1 \mathrm{mg} \mathrm{mL} \mathrm{mL}^{-1}$, while the other solution compounds show either slight or no activity. Most of prepared compounds revealed a good activity against Candida albicans (yeast).

\section{Conclusions}

Three new heterocyclic compounds (5), (6) and (7), have been synthesized derivatives from quinoline molecule while have been characterized through TLC, FTIR and ${ }^{1} \mathrm{H}-\mathrm{NMR}$ spectroscopies.The substantial inference was that the biological efficiency from the top within compound (5) while (7) in order to their include heterogenous pentagonal consist of more oxygen atoms.

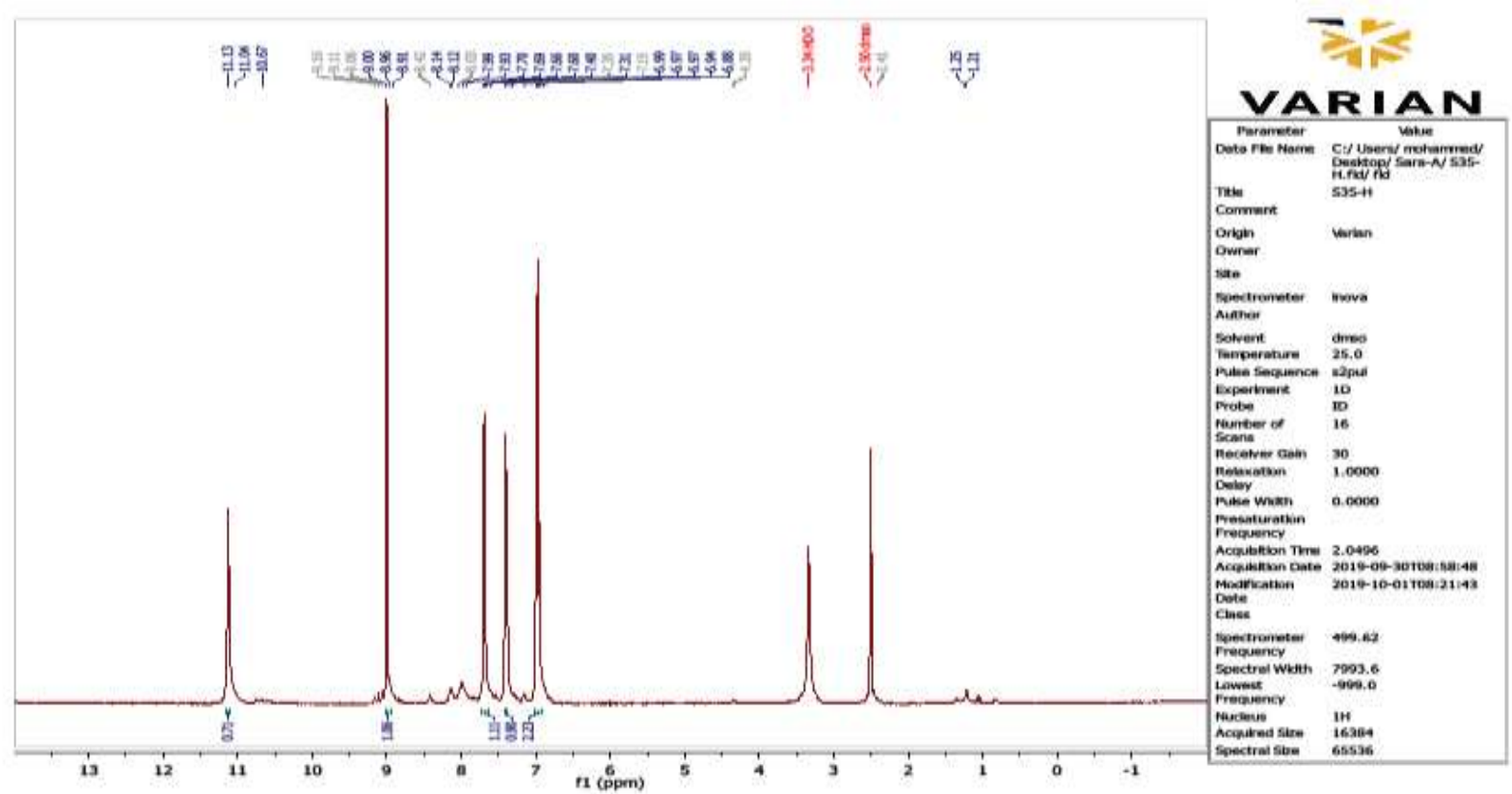

Figure 1. HNMR spectrum of 1, 2-hydroxy-5(4-(3-methyl-5-oxo-4,5-dihydro-1H-pyrazole-1carbonyl)phenyl)diazenyl)benzylideneamino)quinolin-2(1H)-one (5). 


\section{Al-Nahrain Journal of Science}

ANJS, Vol.23 (1), March, 2020, pp. 1 - 6

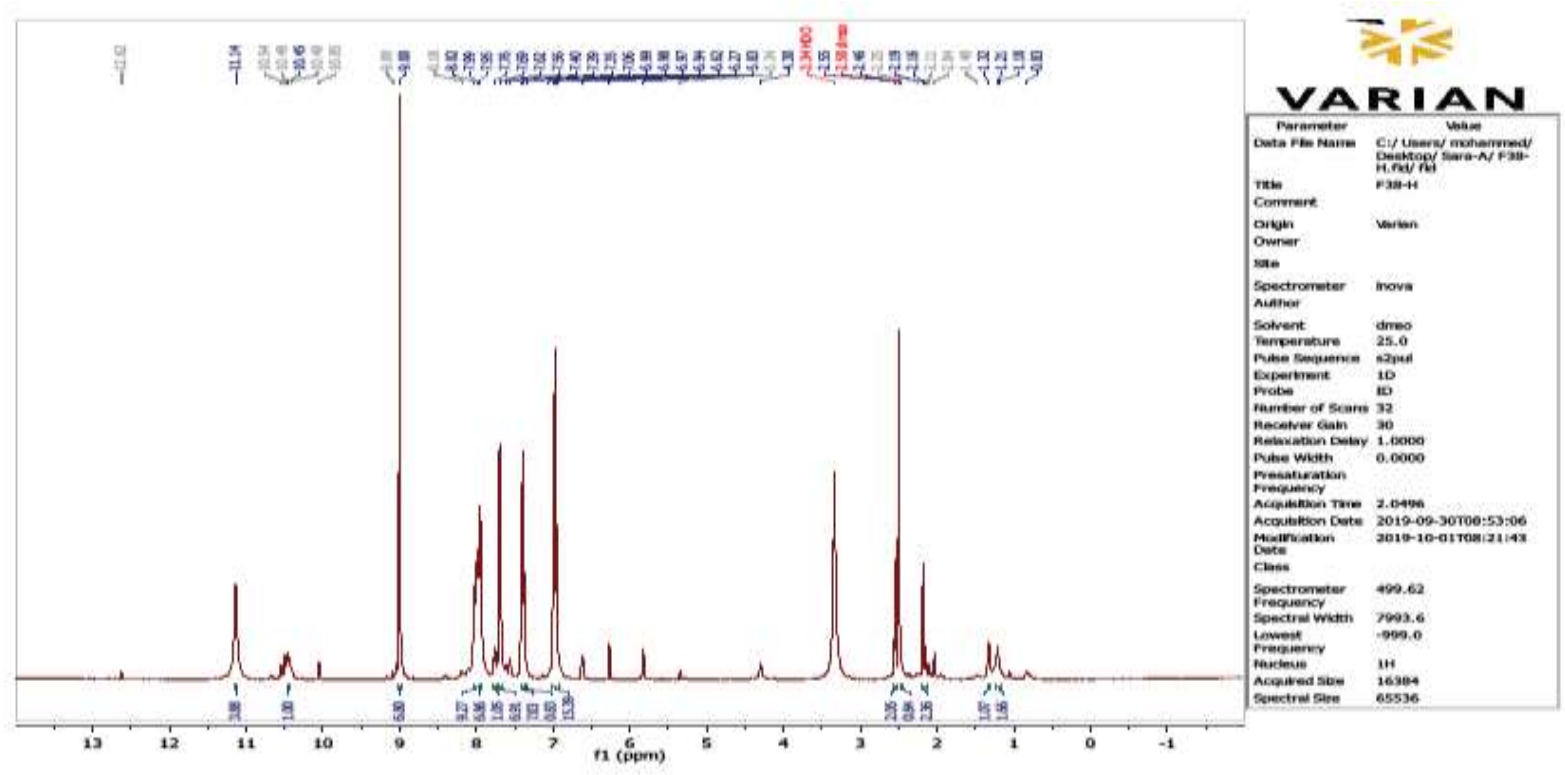

Figure 2. HNMR spectrum of 1,5(4-(3,5-dimethyl-1H-pyrazole-1-carbonyl)phenyl)diazenyl)-2hydroxybenzylideneamino)quinolin-2(1H)-one (6).

\section{References}

[1] Thomas L. Gilchrist; "Heterocyclic Chemistry"; 3rd edition, Addison Wesley: Essex, England; 414, 1997.

[2] Campaigne, E.; "Adrien Albert and the rationalization of heterocyclic chemistry", J. Chem. Edu. 63 (10), 860, 1986.

[3] Banday, R. M.; Matto, H. R.; Rauf, A.; "Synthesis, characterization and anti-bacterial activity of 5 (alkenyl)- 2-amino- and 2-(alkenyl)-5-phenyl-1,3,4oxadiazoles"; J. Chem. Sci. 122 (2), 177-182,2010.

[4] Welsch, M. E., Snyder, S. A., Stockwell, B. R., Privileged scaffolds for library design \&drug discovery, Curr. Opin. Chem. Biol., 14, 347-361, 2010.

[5] Warshakoon, C. N.; Sheville, J.; Bhatt, T. R.; Mendez, A. L. J.; Meyers, M. K.; Kim, N.; Wos, A. J.; Mitchell, C.; Jeennifer, L. P.; Benth, B. P.; Ofer, R.; $\mathrm{Hu}, \mathrm{X}$. E.; "Design and synthesis of substituted quinolines as novel and selective MCHA as antiobesity agents"; Bio-org. Med. Chem. Lett. 16, 5207-5211, 2006.

[6] Chen, Y. L.; Fang, K. C.; Sheu, J. Y.; Hsu, S. L.; Tzeng, C. C.; "Synthesis and antibacterialevaluation of certain quinolone derivatives"; J. Med. Chem. 44, 2374-2377, 2001 .

[7] Ashish, K. T.; Anil, M.; Verma, H. N.; Mishra, A.; "Synthesis and antifungal activity of 4-substituted3,7-dimethyl pyrazolo[3,4-e] [1,2,4] triazine"; Ind. J. Chem. 45B, 489-492, 2006.

[8] El-Emary, T. I.; "Synthesis and biological activity of some new pyrazole[3,4-b]pyrazines"; J. Chin. Chem. Soc. 53, 391-401, 2006.
[9] Farghaly, T. A.; Abass, I. M.; Abdalla, M. M.; Mahgoub, R.; "Synthesis and pharmacological activities of fused pyrimidinones"; World J. Chem. 6, 8-18, 2011.

[10] Al-Bayati, R. I.; Ahmad, M. R.; Ahmed, L. S.; Am. J. Org. Chem. 5(4), 125-135, 2015.

[11] Loganathan, K.; Sithick, K.; Ali, M.; Purushothaman, S. S.; Jamal Abdul Nasser, A.; J. Chem. Pharm. Res. 7(4), 1452-1455, 2015.

[12] Mohammad, M. Y.; Mohammed, A. H.; Vinod, L. P.; Roma, K. P.; Rohit, H. D.; Int. J. Rec. Sci. Res. 9(4G), 26026-26030, 2018

[13] Jafar, N. N.; Majeed, N. S.; "Microwave assisted synthesis of amide derivatives of the drug ciprofloxacin and screening the biological properties"; Int. J. Chem. Tech. Res. 9(7), 387-395, 2016.

[14] Ibraheem, H. H.; Al-Majedy, Y. K.; Salim, A. J.; AlBayati, R. I.; "Synthesis and Characterization of New 1,2-Dihydropyridine-3-Carbonitrile Compounds with Study of Expected Biological Activity"; AlNahrain J. Sci. 21(2), 45-50, 2018.

[15] Al-Bayati, R. I.; Hameed, S. M.; Ibraheem, H. H.; "Synthesis and Characterization of New Coumarin derivatives from Pyrazole derivatives"; Int. J. Appl. Nat. Sci. 4(6), 35-40, 2015.

[16] Sahu, S. K.; Banerjee, M.; Samantray, A.; Behera, C.; Azaml, M. A.; "Synthesis, Analgesic, Antiinflammatory and Antimicrobial Activities of Some Novel Pyrazoline Derivatives"; Trop. J. Pharma. Res. 7 (2), 961-968, 2008. 